\title{
Perbandingan Pengelolaan Rusunawa: Pemilik, Penghuni, Pengelola, Pembiayaan, Luas Unit, Tarif dan Fasilitas
}

\author{
Management Comparison of Low Cost Apartment: Owner, Resident, \\ Operator, Financing, Unit Size, Tariff and Facility
}

\author{
Arry Widya Purnamasari, ${ }^{1, a)}$, Ria Asih Aryani Soemitro ${ }^{1, b)}$ \& Hitapriya Suprayitno ${ }^{1, c)}$ \\ ${ }^{1)}$ Departemen Teknik Sipil, Institut Teknologi Sepuluh November, Surabaya
}

Koresponden : ${ }^{\text {a) }}$ arry.widya@gmail.com, ${ }^{\text {b) }}$ ria@ce.its.ac.id \& ${ }^{c}$ suprayitno.hita@gmail.com

\begin{abstract}
ABSTRAK
Selain pangan dan sandang, rumah merupakan salah satu kebutuhan dasar (basic needs) bagi kehidupan manusia. Terbatasnya lahan dan beragamnya aktivitas masyarakat di perkotaan membutuhkan suatu strategi dalam rangka efisiensi penggunaan lahan, salah satunya adalah pembangunan infrastruktur rumah susun. Di Kota Surabaya terdapat beberapa rumah susun sederhana sewa (Rusunawa) yang dibangun di atas tanah aset pemerintah dengan pola pengelolaan yang berbeda-beda, maka penelitian ini bertujuan untuk mengidentifikasi perbedaan dalam pengelolaan Rusunawa. Hasilnya terdapat beberapa perbedaan antara lain berdasarkan penghuni terdapat 3 kelompok sasaran yaitu: MBR, MBMB dan masyarakat Umum, dimana pembiayaan pembangunan Rusunawa dapat menggunakan APBD/APBD maupun menggunakan kerjasama pemerintah dan swasta. Rusunawa yang dibangun untuk MBR dan MBMB memiliki luas unit hunian yang seragam pada tiap towernya antara $18 \mathrm{~m}^{2}$ hingga $24 \mathrm{~m}^{2}$ dengan tarif yang disubsidi oleh pemerintah serta penyediaan fasilitas yang sederhana. Sedangkan, Rusunawa untuk masyarakat umum dalam satu tower memiliki luasan unit hunian yang bervariasi dari $18 \mathrm{~m}^{2}$ hingga $48 \mathrm{~m}^{2}$ dengan pengenaan tarif komersial serta didukung tersedianya berbagai fasilitas penunjang yang beragam dari jenis dan fungsinya.
\end{abstract}

Kata Kunci : manajemen infrastruktur, Rusunawa, penghuni, pembiayaan tarif, fasilitas

\section{PENDAHULUAN}

Seiring dengan pertumbuhan jumlah penduduk setiap tahunnya berdampak terhadap sistem daya dukung kota dalam menerima, mengatur dan mendayagunakan pendatang. Ketidaksiapan kota mengakomodasi perkembangan aktivitas perkotaan yang semakin beragam berdampak bercampurnya berbagai aktivitas yang terkonsentrasi pada suatu kawasan tertentu mengakibatkan ketidaksesuaian aktivitas dengan rencana sistem pengelolaan perkotaan, munculnya permukiman-permukiman padat penduduk yang tidak layak huni dan rentan kumuh, sehingga dibutuhkan suatu strategi untuk mengatasi berbagai masalah dalam penataan perkotaan tersebut. Dalam pelaksanaan peremajaan lingkungan permukiman tidak bisa dengan cara hanya memberikan ganti rugi kemudian warga tersebut diminta untuk mencari hunian yang lebih baik. Akan tetapi langkah yang lebih baik melakukan strategi redevelopment dalam rangka efisiensi penggunaan lahan, yaitu dengan membangun kembali kawasan kumuh tersebut serta mengganti fisik hunian dari rumah tapak menjadi rumah susun. Hal ini adalah konsekuensi logis dari terbatasnya lahan dan beragamnya aktivitas masyarakat di perkotaan. Pembangunan rumah susun yang layak bagi MBR perlu memperhatikan aspek ekonomi, dimana rumah susun dibangun hendaknya berdekatan dengan tempat kerja, tempat usaha atau tempat berbelanja untuk memenuhi kebutuhan sehari-hari (Yudohusodo,1991). 
Sebagaimana amanat Undang-Undang Nomor 20 Tahun 2011 tentang Rumah Susun, Pemerintah menjamin pemenuhan kebutuhan akan hunian yang layak dan terjangkau bagi masyarakat yang dikategorikan sebagai masyarakat berpenghasilan rendah (MBR) dengan menyediakan infrastruktur berupa rumah susun dalam rangka meningkatkan efisiensi dan efektivitas pemanfaatan ruang, mengurangi luasan dan mencegah timbulnya perumahan dan permukiman kumuh, serta mengarah kepada pengembangan kawasan perkotaan, pemenuhan kebutuhan sosial dan ekonomi. Infrastruktur dibangun untuk menjalankan fungsi tertentu, baik fungsi utama maupun fungsi sekunder lainnya, infrastruktur rumah susun yang dibangun memiliki fungsi utama sebagai perumahan bagi rakyat miskin dan memiliki fungsi sekunder sebagai fasilitas perdagangan dalam skala kecil (Suprayitno \& Soemitro, 2018).

Mempertahankan tingkat jasa pelayanan infrastruktur bertujuan untuk mempertahankan dan meningkatkan kondisi sarana dan prasarana yang telah maupun yang sedang dibangun agar tingkat pelayanannya sesuai dengan kualitas yang disyaratkan, sehingga dapat dioperasikan dan dimanfaatkan semaksimal mungkin. Tahap selanjutnya adalah mengupayakan bagaimana pemeliharaannya, agar nilai ekonomis infrastruktur tersebut tidak menurun dalam rangka menunjang sektor-sektor produktif. Kemudian, apa saja yang harus dilakukan oleh pemerintah, karena yang dihadapi adalah urusan "hidup atau matinya" keuangan negara? Banyak cara memecahkan berbagai persoalan pelayanan infrastruktur, kalau kita mau berpikir secara kreatif, inovatif dan mengambil langkah-langkah yang tidak konvensional (Kwik, 2002).

Di Kota Surabaya terdapat beberapa Rusunawa dibangun di tanah aset pemerintah yang tersebar di berbagai wilayah, dimana Rusunawa tersebut dimiliki dan dikelola dengan pola yang berbeda-beda, terdapat lebih dari 10 buah Rusunawa dengan karakteritik penyelenggaran yang berbeda. Kesepuluh Rusunawa tersebut antara lain : Rusunawa Keputih, Rusunawa Sombo, Rusunawa Wonorejo, Rusunawa Gunganyar, Rusunawa Sumur Welut, dan yang lain. Perbedaan Penyelenggaraan yang berbeda menghasilkan situasi yang berbeda. Perbedaan Penyelenggaran, antara laian terletak pada aspek: investasi atau pengadan Rusunawa, aspek Penghuni Rusunawa, aspek Pemilik Rusunawa (apakah Kota atau Provinsi), aspek penyelengara Rususnawa, dan yang lain. Penyelenggaraan rumah susun dapat dilakasanakan oleh pemerintah melalui APBN/APBD maupun dengan mengikutsertakan badan usaha/swasta dalam kerangka kemitraan. Penyelenggaran rumah susun dianggap sebagai kemitraan sosial yang didedikasikan untuk kelompok berpenghasilan rendah, sehingga harus ada dukungan pemerintah dalam hal kebijakan pembiayaan yang kondusif dan keterlibatan pemerintah dengan memberikan jaminan dan subsidi (Rachmawati. dkk, 2018).

Adanya perbedaaan dalam penyelenggaran Rusunawa, maka diperlukan identifikasi mengenai perbandingan penyelenggaraan Rusunawa berdasarkan kepemilikan, penghunian, lembaga pengelola, pembiayaan, luas unit, tarif dan penyediaan fasilitasnya. Teridentifikasinya variasi penyelenggaraan Rusunawa diharapkan mampu memberikan gambaran bagaimana merencanakan penyelenggaraan Rusunawa agar sesuai kapasitas dan kualitas pelayanan, dengan tetap mempertimbangkan kebutuhan dan keterjangkauan masyarakat.

\section{KAJIAN PUSTAKA}

\section{Penyelenggaraan Infrastruktur Rumah Susun}

Infrastruktur dikembangkan untuk menjalankan fungsi tertentu yang dibutuhkan oleh bidang layanannya. Infrastruktur harus dikelola agar dapat berfungsi secara ekonomis, efisien, efektif, dan harus menghormati prinsip keberlanjutan. Infrastruktur publik harus dikelola oleh tingkat pemerintahan yang berbeda dari tingkat nasional, tingkat provinsi, hingga tingkat kota dan kabupaten. Assignmnet ke tingkat yang berbeda tergantung pada fungsi infrastruktur dan jangkauan area layanan. Setiap infrastruktur memiliki lembaga yang bertanggungjawab sendiri atau badan pengelola (Suprayitno \& Soemitro, 2018; Suprayitno \& Soemitro, 2019). 
Penyelenggaraan infrastruktur rumah susun adalah kegiatan perencanaan, pembangunan, penguasaan dan pemanfaatan, pengelolaan, pemeliharaan dan perawatan, pengendalian, kelembagaan, pendanaan dan sistem pembiayaan, serta peran masyarakat yang dilaksanakan secara sistematis, terpadu, berkelanjutan, dan bertanggung jawab, untuk menjamin terwujudnya rumah susun yang layak huni dan terjangkau dalam lingkungan yang sehat, aman, harmonis, serta menciptakan permukiman yang terpadu guna membangun ketahanan ekonomi, sosial, dan budaya (UU 20/11). Jenis rumah susun seperti pada tabel 1.

Tabel 1. Jenis Rumah Susun

\begin{tabular}{|c|c|c|c|c|}
\hline & $\begin{array}{l}\text { Rumah Susun } \\
\text { Umum }\end{array}$ & $\begin{array}{l}\text { Rumah Susun } \\
\text { Khusus }\end{array}$ & $\begin{array}{l}\text { Rumah Susun } \\
\text { Negara }\end{array}$ & $\begin{array}{l}\text { Rumah Susun } \\
\text { Komersial }\end{array}$ \\
\hline $\begin{array}{l}\text { Kelompok } \\
\text { Sasaran }\end{array}$ & 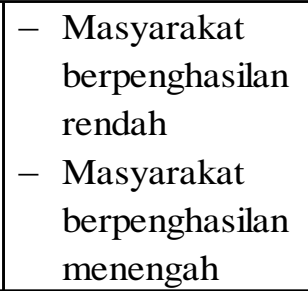 & $\begin{array}{l}\text { Memenuhi } \\
\text { kebutuhan sosial }\end{array}$ & $\begin{array}{l}\text { Pelaksanaan tugas } \\
\text { jabatan dan PNS/ } \\
\text { TNI/ Polri }\end{array}$ & $\begin{array}{l}\text { Masyarakat } \\
\text { memiliki } \\
\text { kemampuan } \\
\text { ekonomi }\end{array}$ \\
\hline $\begin{array}{l}\text { Pelaku/ } \\
\text { Kewenangan }\end{array}$ & $\begin{array}{l}\text { - Pemerintah } \\
\text { - Nirlaba } \\
\text { - Badan Usaha }\end{array}$ & $\begin{array}{l}\text { - Pemerintah } \\
\text { - Nirlaba } \\
\text { - Badan Usaha }\end{array}$ & Pemerintah & $\begin{array}{l}\text { Siapa saja } \\
\text { berbadan hukum }\end{array}$ \\
\hline $\begin{array}{l}\text { Penguasaan, } \\
\text { Pemilikan, dan } \\
\text { Pemanfaatan }\end{array}$ & $\begin{array}{l}\text { - Sewa } \\
\text { - Hak milik }\end{array}$ & $\begin{array}{c}\text { - Pinjam pakai } \\
\text { atau sewa }\end{array}$ & $\begin{array}{l}\text { - Pinjam pakai } \\
- \text { Sewa - beli }\end{array}$ & $\begin{array}{l}- \text { Sewa } \\
\text { - Hak milik }\end{array}$ \\
\hline Pengelola & \begin{tabular}{|l}
- Pemerintah \\
melalui UPT \\
- $\begin{array}{l}\text { Pengelola yang } \\
\text { berbadan }\end{array}$ \\
\end{tabular} & $\begin{array}{l}- \text { Pemerintah } \\
\text { melalui UPT } \\
- \text { Pengelola yang } \\
\text { berbadan }\end{array}$ & $\begin{array}{l}- \text { Pemerintah } \\
\text { melalui UPT } \\
- \text { Pengelola yang } \\
\text { berbadan }\end{array}$ & $\begin{array}{l}\text { Wajib pengelola } \\
\text { yang berbadan } \\
\text { hukum }\end{array}$ \\
\hline
\end{tabular}

Sumber: UU 20/2011

Kewenangan pembangunan rumah susun umum, rumah susun khusus, dan rumah susun negara merupakan tanggung jawab pemerintah, namun dalam pembangunan rumah susun umum dan rumah susun khusus dapat dilaksanakan oleh lembaga nirlaba dan badan usaha. Sedangkan pembangunan rumah susun komersial dapat dilakukan oleh siapa saja berbadan hukum yang memiliki kemampuan untuk menyelenggarakan dengan syarat wajib menyediakan rumah susun umum sekurang-kurangnya $20 \%$ (dua puluh persen) dari total luas lantai rumah susun komersial yang dibangun. Pembangunan rumah susun umum dimaksud dapat dilakukan di luar lokasi kawasan rumah susun komersial namun tetap berada pada kabupaten/kota yang sama. Penguasaan unit satuan rumah susun dapat dilakukan dengan cara disewa, cara pinjampakai, sewa-beli dan hak milik.

Penyediaan hunian yang terjangkau dalam kerangka penyediaan infrastruktur publik membutuhkan dukungan pendanaan dan sistem pembiayaan yang memadai. Infrastruktur publik memiliki karakteristik keuangan terkait biaya dan pendapatan infrastruktur, sepanjang siklus hidupnya. Biaya selalu ada tanpa atau dengan pendapatan apa pun. Infrastruktur tertentu dapat digunakan hanya dengan pembayaran dan infrastruktur lain menghasilkan pendapatan dari kegiatan selain fungsi utamanya (Soemitro \& Suprayitno, 2020). Sumber dana untuk pemenuhan kebutuhan infrastruktur rumah susun, dapat berasal dari:

1. Anggaran Pendapatan dan Belanja Negara (APBN).

Pembangunan rumah susun yang dibiayai menggunakan sumber pendanaan APBN melalui kementerian terkait merupakan bantuan pembangunan rumah susun yang diajukan oleh Kementerian/Lembaga, Pemerintah Propinsi maupun Pemerintah 
Kabupaten/Kota, yang selanjutnya pengelolaannya akan diserahterimakan dengan proses pemindahtangan/hibah. Bantuan meliputi bangunan rumah susun beserta prasarana, sarana dan utilitas umum dengan ketentuan paling tinggi 5 (lima) lantai. Proposal bantuan pembangunan rumah susun yang diajukan mensyaratkan adanya bukti kepemilikan yang sah atas tanah yang dijadikan lahan pembangunan rumah susun baik berupa sertifikat maupun surat penguasaan atas tanah. Selain itu juga didukung dengan surat pernyataan kesesuaian penggunaan lahan dengan rencana tata ruang wilayah, memiliki izin mendirikan bangunan, dukungan pengelolaan sampah, menjamin ketersediaan jaringan listrik dan ketersediaan daya dari Perusahaan Listrik Negara, serta menjamin ketersediaan jaringan air minum dari perusahaan daerah air minum atau sumber air minum yang layak (Permen PUPR 1/18).

2. Anggaran Pendapatan dan Belanja Daerah (APBD).

Pembangunan rumah susun dengan menggunakan alokasi APBD oleh pemerintah daerah pada periode tahun tertentu yang disepakai bersama Dewan Perwakilan Rakyat Daerah.

3. Sumber dana lainnya sesuai dengan ketentuan peraturan perundang-undangan.

Salah satu sumber pendanaan lainnya dalam pembangunan rumah susun adalah dengan mengggunakan Kerjasama Pemerintah dengan Badan Usaha (KPBU) dalam penyediaan infrastruktur untuk kepentingan umum dengan mengacu pada spesifikasi yang telah ditetapkan sebelumnya oleh Menteri/Kepala Lembaga/Kepala Daerah/Badan Usaha Milik Negara/Badan Usaha Milik Daerah, yang sebagian atau seluruhnya menggunakan sumber daya Badan Usaha dengan memperhatikan pembagian risiko diantara para pihak (Perpes 38/15). Pengembalian investasi pembangunan infrastruktur yang dilaksanakan sektor swasta dapat dilakukan dengan mekanisme user fee, dimana pengguna infrastruktur membayar atas pelayanan yang diperolehnya. Namun, sebagaimana rumah susun merupakan infrastruktur sosial yang cenderung hanya memiliki kelayakan secara ekonomi namun tidak layak secara finansial, maka pemerintah dapat memberikan dukungan finansial berupa Availability Payment atas ketersediaan layanan. Availability Payment yang dibayarkan pemerintah dalam skema KPBU tidak dapat dianggap sebagai hutang, melainkan sebagai kewajiban mengikat yang membutuhkan komitmen alokasi pendanaan dalam dokumen pelaksanaan anggaran (Permen PPN/Bappenas No. 4/15).

\section{Kesediaan Membayar Tarif Rusunawa}

Infrastruktur publik umumnya digunakan secara gratis, tetapi infrastruktur publik tertentu dapat digunakan dengan membayar pada tingkat pemanfaatan tertentu, atau dapat pula memperoleh pendapatan dari aktivitas komersial dari infrastruktur itu sendiri. Selain itu ada juga yang bisa mendapatkan pendapatan dari penggabungan beberapa aktivitas seperti komersial, penghapusan infrastruktur, perubahan penggunaan, dan lainnya (Soemitro \& Suprayitno, 2020).

Rumah susun sebagai infrastruktur publik dapat dikenakan tarif atas ketersediaan layanannya yang diatur dalam peraturan pemerintah tentang retribusi, namun masyarakat yang tinggal menepati unit-unit satuan rumah susun (sarusun) umumnya adalah masyarakat yang direlokasi dari kawasan kumuh yang semula dekat dengan lokasi rumah susun, sejak awal menempati rumah susun masyarakat merasa terpaksa menjadi penghuni, sehingga dalam pelaksanaan masyarakat cenderung merasa bahwa keberadaan mereka sudah seharusnya menjadi tanggungjawab pemerintah. Sebagian besar masyarakat menolak diterapkannya semua beban keuangan untuk biaya pemeliharaan dan pengelolaan jika tidak dibantu oleh pemerintah. Hal ini menyebabkan sebagian biaya operasional tetap dituntut untuk ditanggung pemerintah (Subkhan, 2008). 
Kesediaan membayar MBR dapat dilakukan dengan 2 (dua) pendekatan dalam menetapkan kesediaan membayar, yakni willingness to pay (WTP) dan williness to accept (WTA). Definisi WTP adalah sebagai harga tertinggi yang rela dibayarakan oleh setiap pembeli yang diperhitungkan menggunakan pendekatan surplus konsumen dari suatu kurva permintaan. Sedangkan definisi WTA, adalah pengukuran yang dilakukan menggunakan pendekatan pada jumlah minimum pendapatan seseorang untuk mau menerima penurunan (Mankiew, 2004). Pada dasarnya besaran uang sewa ditentukan oleh tarif sewa sesuai dengan kualifikasi hunian yang disewa, yang dipergunakan sebagai biaya pengelolaan rumah susun berdasarkan kebutuhan nyata meliputi biaya operasional, pemeliharaan dan perawatan. Tarif sewa dihitung dan ditetapkan dengan memperhatikan, dasar perhitungan tarif, komponen perhitungan tarif, dan struktur perhitungan tarif sebagaimana tabel 2 berikut.

Tabel 2. Komponen Perhitungan Tarif Sewa Rumah Susun

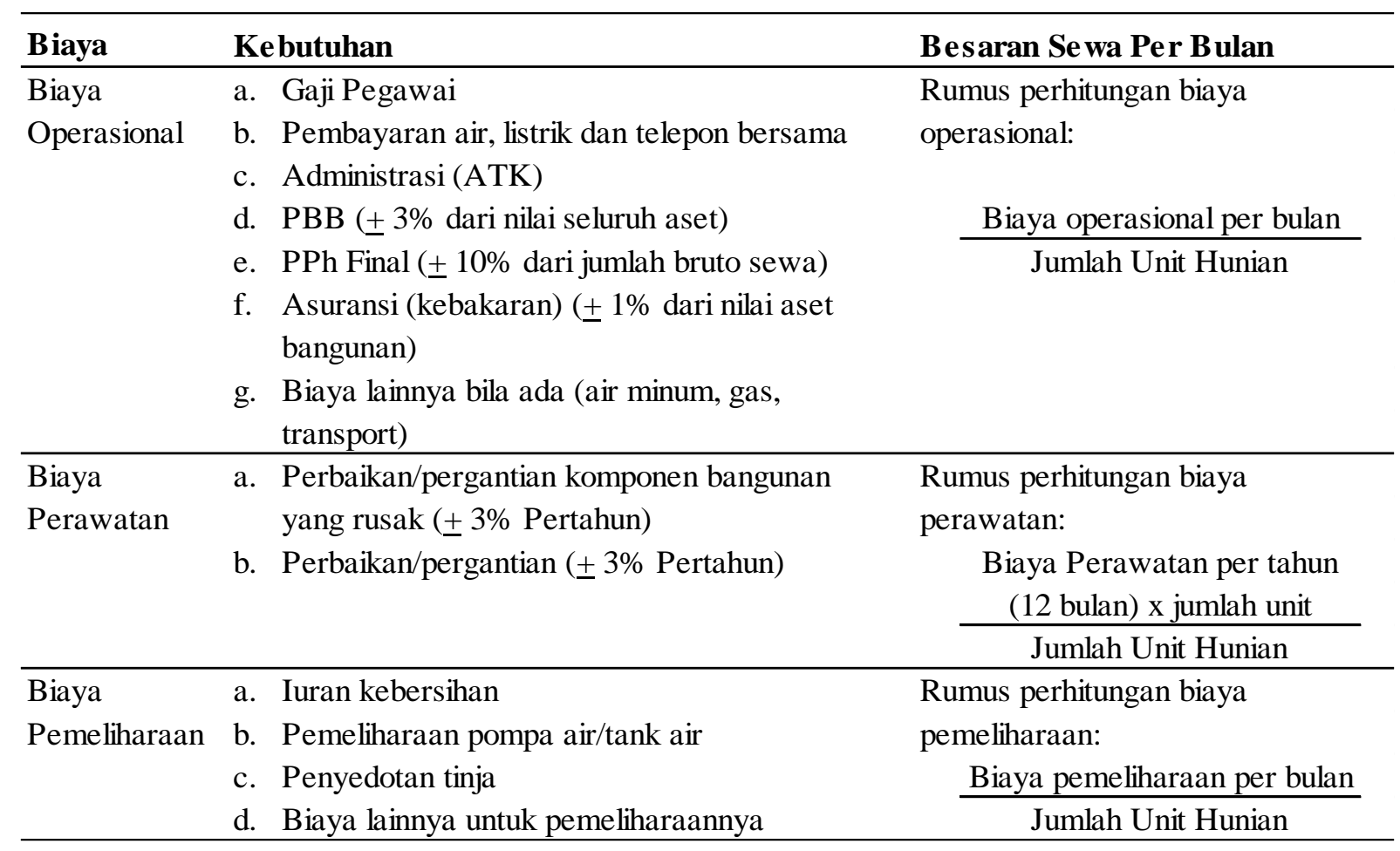

Sumber: Permen PUPR 1/18

Perhitungan besaran tarif sewa satuan rumah susun (sarusun) oleh pengelola tidak lebih besar 1/3 (satu per tiga) dari upah minimum provinsi. Tarif sewa ditetapkan oleh pengguna barang milik negara atau pengelola barang milik daerah dengan Surat Keputusan, dalam hal penetapan tarif sewa berdasarkan komponen dan struktur perhitungan tarif ternyata tidak dapat dijangkau oleh penghuni maka Pemerintah Pusat atau Pemerintah Daerah dapat memberikan subsidi tarif sewa sarusun sesuai kewenangannya. Struktur tarif sewa dibagi dalam tiga kelompok, terdiri dari:

- Tarif sewa sosial, adalah tarif sewa yang ditetapkan berdasarkan perhitungan biaya pemeliharaan dan perawatan rutin termasuk eskalasi harga karena inflasi. Tarif sewa sosial diperuntukkan bagi masyarakat berpenghasilan rendah (MBR).

- Tarif tarif sosial maksimum atau sewa dasar adalah tarif sewa yang ditetapkan dengan memperhitungkan biaya operasional, biaya pemeliharaan, dan perawatan termasuk eskalasi harga karena inflasi. Tarif sewa dasar diperuntukkan bagi masyarakat berpenghasilan menengah bawah (MBMB). 
- Tarif sewa komersial, adalah tarif sewa yang ditetapkan dengan memperhitungkan biaya investasi, biaya operasional, biaya pemeliharaan, dan biaya perawatan termasuk eskalasi harga karena inflasi. Tarif sewa komersial diperuntukkan bagi masyarakat golongan menengah atas.

\section{Fasilitas Rumah Susun}

Fasilitas diartikan sebagai objek fisik maupun objek non fisik, yang pertama fasilitas adalah sebagai instalasi pelengkap bagi suatu infrastruktur. Kedua, fasilitas adalah sebagai sesuatu yang diperlukan bagi kehidupan baik berupa objek fisik maupun objek non fisik. Lebih lanjut fasilitas merupakan bagian dari suatu lingkungan hidup suatu wilayah, dimana dimana keberadaan suatu fasilitas sengaja diadakan untuk memperbaiki dan/atau menjaga kualitas lingkungan hidup tetap baik atau menjadi lebih baik. Keberadaan fasilitas mengikuti fenomena permintaan-penawaran, sehingga pengadaan fasilitas harus disesuaikan dengan kebutuhan dalam bentuk dan ukuran yang bermacam-macam. (Soemitro \& Suprayitno, 2018).

Penyelenggaran rumah susun wajib dilengkapi fasilitas lingkungan rumah susun berupa utilitas umum, prasarana dan saranadengan mempertimbangkan kemudahan dan keserasian hubungan dalam kegiatan sehari-hari dimana struktur, ukuran dan kekuatan sesuai dengan fungsi dan penggunaannya serta pengamanan jika terjadi hal-hal yang membahayakan. Sarana rumah susun merupakan fasilitas dalam lingkungan hunian rumah susun yang berfungsi untuk mendukung penyelenggaraan dan pengembangan kehidupan sosial, ekonomi dan budaya. Sarana yang dimaksud meliputi sarana pendidikan, kesehatan, peribadatan dan perniagaan, selain itu juga wajib dilengkapi sarana umum berupa ruang terbuka hijau, tempat rekreasi, sarana olahraga, dan sarana pemerintahan (UU 20/11).

\section{METODOLOGI PENELITIAN}

Metode penelitian ini menggunakan metode deskriptif analitik dengan mengumpulkan data di lapangan berupa pengamatan (observasi) dan studi kepustakaan yang objek utamanya adalah buku, peraturan-perundangan, naskah akademik, artikel jurnal, laporan proyek, atau sumber literatur lainnya, atau hasil kajian tesis/disertasi penelitian sebelumnya. Kesimpulan yang didapat dalam penelitian ini mampu mendeskripsikan gambaran nyata yang ada di lapangan berupa identifikasi perbedaan penyelenggaraan Rusunawa pada objek penelitian berupa kepemilikan, sasaran penghuni, lembaga pengelola, sistem dan sumber pembiayaan, luasan unit, pengenaan tarif dan ketersediaan fasilitas.

\section{PENGUMPULAN DATA}

Data yang digunakan dalam penelitian ini adalah data sekunder yang dihimpun secara institusional maupun melalui studi kepustakaan yang relevan berupa peraturan-perundangan, naskah akademik, artikel jurnal, laporan proyek, atau sumber literatur lainnya, sedangkan data primer dihimpun melalui observasi langsung Rusunawa. Dalam penelitian berfokus pada rumah susun umum yang dibangun di atas tanah aset pemerintah yang pemanfaatannya dengan cara sewa, yang selanjutnya disebut sebagai Rusunawa, dimana yang menjadi objek penelitian ini adalah Rusunawa Penjaringan Sari, Rusunawa Warugunung dan Rusunawa Siwalankerto.

\section{ANALISIS PERBANDINGAN}

\section{Tinjauan Umum Objek Penelitian}

Dalam penelitian ini yang menjadi objek penelitian adalah 3 Rusunawa yang berada di Kota Surabaya yakni Rusunawa Penjaringan Sari, Rusunawa Warugunung dan Rusunawa Siwalankerto. Ketiga Rusunawa tersebut dimiliki dan dikelola dengan pola yang berbeda-beda. Sehingga, ketiga Rusunawa tersebut memiliki perbedaan karakteristik baik dari segi pemilik, 
penghuni, pengelola, pembiayaan, luas unit, tarif dan penyediaan fasilitasnya. Adapun profil dari ketiga Rusunawa tersebut diuraikan dalam Tabel 3 berikut ini.

Tabel 3. Profil Rusunawa Objek Penelitian

\begin{tabular}{|c|c|c|c|}
\hline & \multicolumn{3}{|c|}{ Rusunawa } \\
\hline & Penjaringan Sari & Warugunung & Siwalankerto \\
\hline Lokasi & $\begin{array}{l}\text { Jl. Penjaringan Sari, } \\
\text { Kecamatan Rungkut, Kota } \\
\text { Surabaya }\end{array}$ & $\begin{array}{l}\text { Kelurahan Warugunung, } \\
\text { Kecamatan Karang Pilang Kota } \\
\text { Surabaya }\end{array}$ & $\begin{array}{l}\text { Jl. Siwalankerto Timur, } \\
\text { Kecamatan Wonocolo, Kota } \\
\text { Surabaya }\end{array}$ \\
\hline $\begin{array}{l}\text { Kepemilikan } \\
\text { Aset Tanah }\end{array}$ & $\begin{array}{l}\text { Milik Pemerintah Kota } \\
\text { Surabaya }\end{array}$ & Milik Pemerintah Kota Surabaya & $\begin{array}{l}\text { Milik Pemerintah Provinsi } \\
\text { Jawa Timur }\end{array}$ \\
\hline $\begin{array}{l}\text { Kepemilikan } \\
\text { Aset } \\
\text { Bangunan } \\
\end{array}$ & $\begin{array}{l}\text { Milik Pemerintah Kota } \\
\text { Surabaya }\end{array}$ & $\begin{array}{l}\text { Milik PT. Perum Perumnas s.d } \\
\text { penyelesaian pengembalian } \\
\text { investasi }\end{array}$ & $\begin{array}{l}\text { Milik Pemerintah Provinsi } \\
\text { Jawa Timur }\end{array}$ \\
\hline Jumlah Tower & 10 tower $t$ win block, 5 lantai. & 10 tower twin block, 5 lantai. & 5 tower twin block, 5 lantai. \\
\hline Tipe Hunian & $\begin{array}{l}4 \text { tower tipe } 18 \mathrm{~m}^{2} \\
4 \text { tower tipe } 21 \mathrm{~m}^{2} \\
2 \text { tower tipe } 24 \mathrm{~m}^{2}\end{array}$ & 10 tower, tipe $21 \mathrm{~m}^{2}$ & $\begin{array}{l}\text { Tipe bervariasi, yaitu: } \\
18 \mathrm{~m}^{2}, 24 \mathrm{~m}^{2}, 28 \mathrm{~m}^{2} \\
30 \mathrm{~m}^{2}, 36 \mathrm{~m}^{2}, 48 \mathrm{~m}^{2}\end{array}$ \\
\hline Luas Lahan & $32.350 \mathrm{~m}^{2}$ & $35.286 \mathrm{~m}^{2}$ & $\pm 22.000 \mathrm{~m}^{2}$ \\
\hline Pengelola & $\begin{array}{l}\text { UPTD Dinas Pengelolaan } \\
\text { Bangunan dan Tanah Pemkot } \\
\text { Surabaya. }\end{array}$ & $\begin{array}{l}\text { UPTD Dinas Pengelolaan } \\
\text { Bangunan dan Tanah Pemkot } \\
\text { Surabaya. }\end{array}$ & $\begin{array}{l}\text { BUMD PT. Jatim Grha } \\
\text { Utama }\end{array}$ \\
\hline
\end{tabular}

\section{Analisis Perbandingan Pemilik, Penghunian dan Lembaga Pengelola}

Sasaran utama Rusunawa Penjaringan Sari adalah warga kota Surabaya (berdasar kepemilikan KTP), belum memiliki rumah dan berpenghasilan rendah. Rusunawa Penjaringan Sari I dan II merupakan relokasi warga yang digusur dari beberapa kawasan permukiman ilegal di Surabaya, terutama dari kawasan Karang Menjangan dan kawasan pinggir sungai. Sedangkan Rusunawa Penjaringan Sari III dan Penjaringan Sari IV dihuni oleh warga umum (bukan warga relokasi) berpenghasilan rendah yang bekerja di sekitar wilayah industri Rugkut. Rusunawa Penjaringansari dikelola oleh UPT Dinas Pengelolaan Bangunan dan Tanah Pemkot Surabaya. Seleksi penghuni dilakukan oleh Dinas Pengelolaan Bangunan dan Tanah, dan bukan dilakukan oleh UPTD yang bertindak selaku pengelola lokasi Rusunawa.

Sasaran Penghunian bagi Rusunawa Warugunung agak berbeda dengan sasaran bagi Rusunawa Penjaringan Sari. Rusunawa Warugunung ditujukan bagi Masyarakat Berpenghasilan Menengah Bawah (MBMB). Kelompok masyarakat ini berpenghasilan relative lebih tinggi dari pada MBR. Rusunawa Warugung ini pun dikelola oleh UPT Dinas Pengelolaan Bangunan dan Tanah, Pemkot Surabaya.

Rusunawa Siwalankerto adalah milik Pemerintah Provinsi Jawa Timur. Rusunawa ini diperuntukkan masyarakat umum. Pengelolaan Rusunawa Siwalankerto ditugaskan kepada PT. Jatim Grha Utama (PT. JGU), sebuah Badan Usaha Milik Daerah (BUMD) milik Pemerintah Provinsi Jawa Timur, Skema kerjasama antara Pemerintah Provinsi Jawa Timur dengan PT. Jatim Grha Utama (PT. JGU) adalah skema kontrak manajemen (Management Contract), dimana PT. JGU menjalankan fungsi pengelolaan dan penyediaan jasa layanan Rusunawa dengan menggunakan aset infrastruktur dan sarana yang telah dibangun atau dimiliki oleh Pemerintah.

Perbandingan Aspek Penghunian dan Pengelolaan bagi ketiga Rusunawa obyek penelitian bisa diringkas sebagai berikut. Pengelolaan Rusunawa yang ditujukan unutk MBR dan MBMB merupakan Kegiatan Sosial, jadi harus dilakukan oleh UPT Pemerintah Daerah. Pengelolaan Rusunawa bagi masyarakat umum merupakan kegiatan komersial, sehingga 
pengelolaannya dapat dikerjasamakan dengan sebuah Badan Usaha. Ringkasan ini bisa dilihat pada Tabel 4 sebagai berikut.

Tabel 4. Perbandingan Pemilik, Penghunian dan Lembaga Pengelola

\begin{tabular}{l|lll}
\hline \multicolumn{2}{c}{} & \multicolumn{3}{c}{ Rusunawa } \\
\cline { 2 - 4 } & Penjaringansari & Warugunung & Siwalanke rto \\
\hline Pemilik & PemKot Surabaya & PemKot Surabaya & PemProv Jawa Timur \\
\hline Penghuni & 9 Tower MBR & MBMB & $\begin{array}{l}\text { Masyarakat Umum yang } \\
\text { mampu membayar sewa }\end{array}$ \\
& 1 Tower MBMB & & \\
& warga Kota Surabaya & warga Kota Surabaya & \\
& syarat : & syarat : & \\
& KTP Surabaya & KTP Surabaya & \\
& Belum mempunyai & Belum mempunyai & \\
& rumah & rumah & PT JGU \\
\hline Pengelola & UPT Dinas & UPT Dinas & BUMD PemProv Jatim \\
\hline
\end{tabular}

\section{Analisa Perbandingan Pembiayaan}

Rusunawa Penjaringan Sari adalah salah satu contoh penyediaan rumah susun yang sepenuhnya menggunakan alokasi APBN oleh kementerian terkait, pembangunannya dilaksanakan secara bertahap pada lahan milik Pemerintah Kota Surabaya. Pengelolaan Rusunawa Penjaringan Sari diserahkan kepada Pemerintah Kota Surabaya.

Rusunawa Warugunung merupakan contoh pembangunan rumah susun dengan pembiayaan Kerjasama Pemerintah Swasta (KPS) atau saat ini disebut dengan Kerjasama Pemerintah dengan Badan Usaha (KPBU). KPS dilaksanakan antara Pemerintah Kota Surabaya dengan Perumnas sesuai Perjanjian Kerjasama No.648.21/3938.3/402.601/96 dan No.DIRUT/525/22/IX/96 dengan skema Bangun, Serah, Kelola. Rusunawa ini sendiri dibangun di atas tanah milik Pemerintah Kota Surabaya, pengalihan atas aset yang telah terbangun sesuai Perjanjian Kerjasama No.648.21/1412.1/402.601/97 dan No.DIRUT/507/22/V/97 dengan masa pengembalian investasi kepada PT Perum Perumnas selama 26 tahun. Dalam perjanjian tersebut dinyatakan bahwa Bangunan merupakan milik PT Perum Perumnas sampai dengan Pemerintah Kota Surabaya menyelesaikan pengembalian investasi tersebut. CaLK Audited Pemerintah Kota Surabaya tahun 2015 mencatat pengembalian biaya investasi yang harus dibayar kepada Perumnas adalah sebesar Rp 4.969.192.500,00 sedangkan yang telah dibayar sampai dengan tahun 2015 adalah sebesar Rp 1.298.340.952,00.

Biaya operasional, pemeliharaan dan perawatan Rusunawa yang pengelolaannya oleh Pemerintah Kota Surabaya,dilaksanakan dibawah Dinas Pengelolaan Bangunan dan Tanah Pemkot Surabaya dengan UPTD sebagai pengelola seperti Rusunawa Penjaringan Sari dan Rusunawa Warugunung tidak sepenuhnya berdasarkan tarif yang dibebankan kepada penghuni, sehingga Pemerintah Kota Surabaya menganggarkan subsidi berupa biaya operasional, pemeliharaan dan perawatannya pada APBD setiap tahunnya.

Untuk Rusunawa Siwalankerto pembangunannya terbagi dalam 3 tahap dengan sistem pembiayaan yang berbeda. Pembangunan Tahap I pada 2004 dilakukan dengan kerjasama pembangunan dengan menggandeng PT. Perum Perumnas berupa 2 twin block, kemudian dialihkan haknya pada Pemerintah Provinsi Jawa Timur dengan sistem angsur sampai tahun 2005 menggunakan APBD. Tahap II dilaksanakan pada tahun 2006 berupa 2 twin block dengan menggunakan hibah bantuan pembangunan menggunakan APBN. Tahap III dilaksanakan pada tahun 2008 berupa pembangunan 1 twin block menggunakan APBD Pemerintah Provinsi Jawa Timur dengan anggaran lebih kurang Rp7,3 milyar (AP Indonesia, 2008). Setelah selesai masa 
pembangunan pengelolaan Rusunawa Siwalankerto masih belum berjalan optimal, sehingga kemudian Pemerintah Provinsi Jawa Timur menunjuk PT. JGU sebagai pengelola Rusunawa tersebut dengan menerbitkan Peraturan Gubernur Jawa Timur No. 39 Tahun 2009 dan Surat Gubernur Jawa Timur No.648/493/112/2011 tentang Pengelolaan Sementara Rusun Siwalankerto. Biaya operasional, pemeliharan dan perawatan rutin Rusunawa Siwalankerto murni berasal dari pengenaan tarif yang dibebankan kepada penghuni (user fee).

Dari hasil perbandingan pembiayaan, baik pembiayaan investasi maupun pengembalian investasi pembangunan yang dilaksanakan swasta, seluruhnya adalah tanggungjawab pemerintah dengan menggunakan APBN maupun APBD. Namun, terjadi perbedaan pada pembiayaan operasional, pemeliharaan dan perawatan, dimana Rusunawa yang pengelolannya oleh Dinas melalui UPT yang diperuntukan bagi masyakat berpenghasilan rendah (MBR) dan masyarakat berpenghasilan menengah bawah (MBMB) dalam operasionalnya memperoleh subsidi dari pemerintah. Sedangkan, Rusunawa yang pengelolaannya dikerjasamakan dengan pihak swasta menyasar kepada masyarakat umum yang mampu membayar sewa, seluruh biaya operasional dibebankan penghuni. Rangkuman perbandingan pembiayaan seperti pada Tabel 5 sebagai berikut.

Tabel 5. Perbandingan Pembiayaan

\begin{tabular}{|c|c|c|c|}
\hline & \multicolumn{3}{|c|}{ Rusunawa } \\
\hline & Penjaringan Sari & Warugunung & Siwalankerto \\
\hline Tahun & - Tahap I 1998 Hibah & 1996 / PT. Perum & - Tahap I 2004 PT \\
\hline Pembangunan & APBN & Perumnas berupa & Perum Perumnas, \\
\hline dan Sumber & - Tahap II 2002-2004 & Bangun, Serah, Kelola & Pengembalian \\
\hline Dana & Hibah APBN & (BSK) dengan masa & investasi dengan \\
\hline \multirow[t]{5}{*}{ Pembangunan } & - Tahap III 2009-2010 & pengembalian investasi & sistem cicilan, selesai \\
\hline & Hibah APBN & selama 26 tahun & - Tahap II 2006 Hibah \\
\hline & - Tahap IV 2017-2018 & & APBN \\
\hline & Hibah APBN & & - Tahap III 2008 APBD \\
\hline & & & $\begin{array}{l}\text { Pemerintah Provinsi } \\
\text { Jawa Timur }\end{array}$ \\
\hline$\overline{\text { Biaya }}$ & - Tarif sewa & - Tarif sewa & Sepenuhnya menggunkan \\
\hline Operasional & - Subsidi APBD & - Subsidi APBD & Tarif sewa (userfee) \\
\hline & Pemerintah Kota & Pemerintah Kota & \\
\hline Pemeliharaan & Surabaya & Surabaya & \\
\hline
\end{tabular}

\section{Analisis Perbandingan Luas Unit dan Tarif}

Dalam penyelenggaran rumah susun selain biaya pembangunan, juga mencakup biaya pengelolaan berupa operasional, pemeliharaan dan perawatan bangunan gedung. Sumber dana perawatan tidak berbeda dari anggaran untuk operasional dan pemeliharaan, terutama untuk anggaran perawatan yang bersifat rutin dapat dibebankan pada tarif sewa secara proporsional kepada penghuni. Sedangkan untuk perawatan yang bersifat rehabilitasi, renovasi, dan restorasi, atau adanya kerusakan sedang, berat dan perawatan khusus maka menjadi tanggung jawab Pemerintah sebagai pemilik Rusunawa (UU 20/2011).

Tarif sewa yang ditetapkan untuk penghuni tidak termasuk penggunaan air, gas, listrik dan/atau telepon yang dipergunakan oleh penghuni. Pemerintah daerah dapat mensubsidi biaya operasional dan pemeliharaan menggunakan alokasi dana APBD sesuai dengan kewenangannnya. Sebagaimana diatur Peraturan Pemerintah Nomor 38 Tahun 2008, berbunyi "Biaya pemeliharaan barang milik negara/daerah dibebankan pada Anggaran Pendapatan dan Belanja Negara/Daerah", sepanjang tidak ada kerjasama pemanfaatan Rusunawa dengan pihak 
lain. Biaya anggaran pemeliharaan bangunan Rusunawa digunakan dalam rangka mempertahankan gedung dan bangunan kantor dengan tingkat kerusakan kurang dari atau sampai dengan $2 \%$ (termasuk cleaning service).

Contoh pengenaan tarif sewa sosial minimum dengan memperhitungkan biaya pemeliharaan dan perawatan rutin termasuk eskalasi harga karena inflasi, yang ditetapkan berdasarkan perhitungan kebutuhan biaya pemeliharaan setiap bulan dibagi jumlah satuan rumah susun, seperti yang diberlakukan pada Rusunawa Penjaringan Sari II dan Rusunawa Penjaringan Sari III sebagaimana dalam Tabel 6 berikut.

Tabel 6. Contoh Tarif Sewa Sosial Minimum di Kota Surabaya

\begin{tabular}{llrrrl}
\hline \multirow{2}{*}{ Rumah Susun } & Tower & $\begin{array}{l}\text { Lantai } \\
\text { Hunian }\end{array}$ & $\begin{array}{l}\text { Tipe } \\
\text { Hunian }\end{array}$ & \multicolumn{2}{l}{ Tarif Se wa per } \\
Bulan (Rp) & Dasar Hukum \\
\hline Penjaringan & DA-DB, & I & $21 \mathrm{~m}^{2}$ & $59.000,-$ & Peraturan Walikota \\
Sari II & EA-EB, & II & $21 \mathrm{~m}^{2}$ & $53.000,-$ & Surabaya Nomor 5 \\
& FA-FB. & III & $21 \mathrm{~m}^{2}$ & $47.000,-$ & Tahun 2020 tentang \\
& & IV & $21 \mathrm{~m}^{2}$ & $38.000,-$ & Tarif Sewa Rumah \\
& & I & $24 \mathrm{~m}^{2}$ & $76.000,-$ & Susun Sederhana \\
Penjaringan & Penjaringan & II & $24 \mathrm{~m}^{2}$ & $69.000,-$ & Pengelolaan \\
Sari III & Sari 3 & III & $24 \mathrm{~m}^{2}$ & $61.000,-$ & Pemerintah Kota \\
& & IV & $24 \mathrm{~m}^{2}$ & $50.000,-$ & Surabaya. \\
& & V & $24 \mathrm{~m}^{2}$ & $34.000,-$ & \\
\hline
\end{tabular}

Selanjutnya contoh pengenaan tarif sosial maksimum atau tarif sewa dasar meliputi biaya pemeliharaan, perawatan dan biaya operasional yang ditetapkan berdasarkan perhitungan setiap bulan dibagi jumlah satuan rumah susun, diberlakukan pada Rusunawa Penjaringan Sari III dan Rusunawa Warugunung, sebagaimana disajikan seperti dalam Tabel 7 berikut.

Tabel 7. Contoh Tarif Sewa Sosial Maksimum di Kota Surabaya

\begin{tabular}{llcrrl}
\hline \multirow{2}{*}{ Rumah Susun } & Tower & $\begin{array}{c}\text { Lantai } \\
\text { Hunian }\end{array}$ & $\begin{array}{l}\text { Tipe } \\
\text { Hunian }\end{array}$ & \multicolumn{2}{l}{ Tarif Sewa per } \\
Bulan (Rp) & Dasar Hukum \\
\hline Penjaringan & Penjaringan & I & $24 \mathrm{~m}^{2}$ & $96.000,-$ & Peraturan Walikota \\
Sari IV & Sari 4 & II & $24 \mathrm{~m}^{2}$ & $86.000,-$ & Surabaya Nomor 5 \\
& & III & $24 \mathrm{~m}^{2}$ & $76.000,-$ & Tahun 2020 tentang \\
& & IV & $24 \mathrm{~m}^{2}$ & $62.000,-$ & Tarif Sewa Rumah \\
\hline Warugunung & Blok 1 sd & I & $21 \mathrm{~m}^{2}$ & $126.000,-$ & Sewa dalam \\
& Blok 10 & II & $21 \mathrm{~m}^{2}$ & $120.000,-$ & Pengelolaan \\
& & III & $21 \mathrm{~m}^{2}$ & $114.000,-$ & Pemerintah Kota \\
& & IV & $21 \mathrm{~m}^{2}$ & $108.000,-$ & Surabaya. \\
& & V & $21 \mathrm{~m}^{2}$ & $102.000,-$ & \\
\hline
\end{tabular}

Sedangkan, Rusunawa Siwalankerto yang pengelolaan dan penyediaan jasa layanannya dikerjasamakan antara Pemerintah Provinsi Jawa Timur dan PT. JGU, adalah contoh penetapan tarif sewa komersial, dimana perhitungan tarif berdasarkan kebutuhan nyata operasional, pemeliharaan dan perawatan yang murni dibebankan kepada penghuni. Keputusan pengenaan 
tarif diatur sendiri oleh PT. JGU tanpa membutuhkan persetujuan dari Pemerintah Provinsi Jawa Timur, dapat dilihat Tabel 8 berikut ini.

Tabel 8. Contoh Tarif Sewa Komersial di Kota Surabaya

\begin{tabular}{|c|c|c|c|c|c|c|}
\hline \multirow[b]{2}{*}{ Rumah Susun } & \multirow{2}{*}{$\begin{array}{l}\text { Lantai } \\
\text { Hunian }\end{array}$} & \multicolumn{4}{|c|}{ Tarif Se wa per Tipe Hunian / Bulan (Rp) } & \multirow[b]{2}{*}{ Das ar Hukum } \\
\hline & & \multicolumn{2}{|c|}{ Tower A, B, D, E } & \multicolumn{2}{|c|}{ Tower C } & \\
\hline \multirow[t]{16}{*}{ Siwalankerto } & I & $48 \mathrm{~m}^{2}$ & 1.655.000,- & $36 \mathrm{~m}^{2}$ & 1.242.000,- & - Peraturan \\
\hline & & $36 \mathrm{~m}^{2}$ & 1.148.000,- & $28 \mathrm{~m}^{2}$ & $999.000,-$ & Gubernur Jawa \\
\hline & & $28 \mathrm{~m}^{2}$ & 951.000,- & $24 \mathrm{~m}^{2}$ & 873.000,- & Timur No. 39 \\
\hline & II & $48 \mathrm{~m}^{2}$ & 1.472.000,- & $36 \mathrm{~m}^{2}$ & 1.105.000,- & Tahun 2009 \\
\hline & & $36 \mathrm{~m}^{2}$ & 1.302.000,- & $28 \mathrm{~m}^{2}$ & 889.000,- & - Surat Gubernur \\
\hline & & $28 \mathrm{~m}^{2}$ & 844.000,- & $24 \mathrm{~m}^{2}$ & $780.000,-$ & \\
\hline & III & $48 \mathrm{~m}^{2}$ & 1.251.000,- & $36 \mathrm{~m}^{2}$ & 929.000,- & $\begin{array}{l}\text { No.648/493/112/ } \\
2011 \text { tentang }\end{array}$ \\
\hline & & $36 \mathrm{~m}^{2}$ & 879.000,- & $28 \mathrm{~m}^{2}$ & 763.000,- & Pengelolaan \\
\hline & & $28 \mathrm{~m}^{2}$ & 706.000,- & $24 \mathrm{~m}^{2}$ & 693.000,- & Sementara \\
\hline & IV & $48 \mathrm{~m}^{2}$ & 1.086.000,- & $48 \mathrm{~m}^{2}$ & $814.000,-$ & Rusun \\
\hline & & $36 \mathrm{~m}^{2}$ & 786.000,- & $36 \mathrm{~m}^{2}$ & 659.000,- & Siwalankerto \\
\hline & & $28 \mathrm{~m}^{2}$ & 604.000,- & $28 \mathrm{~m}^{2}$ & $586.000,-$ & \\
\hline & $\mathrm{V}$ & $30 \mathrm{~m}^{2}$ & 490.000,- & $30 \mathrm{~m}^{2}$ & 490.000,- & \\
\hline & & $28 \mathrm{~m}^{2}$ & 479.000,- & $28 \mathrm{~m}^{2}$ & 479.000,- & \\
\hline & & $24 \mathrm{~m}^{2}$ & 410.000,- & $24 \mathrm{~m}^{2}$ & 410.000,- & \\
\hline & & $18 \mathrm{~m}^{2}$ & 299.000,- & $18 \mathrm{~m}^{2}$ & 299.000,- & \\
\hline
\end{tabular}

Dari hasil analisa tarif, Rusunawa dengan sasaran penghuni kelompok MBR dan MBMB memiliki tarif yang lebih rendah dibandingkan dengan Rusunawa penghuni umum bahkan pada tipe/luas unit per $\mathrm{m}^{2}$ yang sama. Penetapan tarif kelompok MBR dan MBMB berdasarkan Peraturan Kepala Daerah, sedangkan utuk kelompok umum ditetapkan oleh badan pengelola rumah susun tanpa melibatkan pemerintah. Perbandingan luasan unit per $\mathrm{m}^{2}$ yang sama dan tarif sewa Rusunawa memiliki perbedaan antara kelompok sasaran MBR dan MBMB dengan masyarakat umum, sebagaimana ditampilkan pada Tabel 9 berikut.

Tabel 9. Hasil Perbandingan Luas Unit dan Tarif

\begin{tabular}{|c|c|c|c|c|c|}
\hline \multirow{3}{*}{$\frac{\text { Rusunawa }}{\text { Penjaringan Sari II }}$} & \multirow{3}{*}{$\frac{\text { Penghuni }}{\text { MBR }}$} & \multicolumn{4}{|c|}{ Perbandingan Luas Unit dengan Tarif Se wa/ Bulan (Rp) } \\
\hline & & Variasi Unit & Luas Unit & Tarif Se ws & \\
\hline & & $\begin{array}{l}\text { Seragam dalam } 1 \\
\text { Tower }\end{array}$ & $21 \mathrm{~m}^{2}$ & $\begin{array}{l}\text { Tertunggi } \\
\text { Terendah }\end{array}$ & $\begin{array}{l}59.000,- \\
38.000,-\end{array}$ \\
\hline Warugunung & MBMB & $\begin{array}{l}\text { Seragam dalam } 1 \\
\text { Tower }\end{array}$ & $21 \mathrm{~m}^{2}$ & $\begin{array}{l}\text { Tertunggi } \\
\text { Terendah }\end{array}$ & $\begin{array}{l}126.000,- \\
102.000,-\end{array}$ \\
\hline Penjaringan Sari III & MBR & $\begin{array}{l}\text { Seragam dalam } 1 \\
\text { Tower }\end{array}$ & $24 \mathrm{~m}^{2}$ & $\begin{array}{l}\text { Tertunggi } \\
\text { Terendah }\end{array}$ & $\begin{array}{l}76.000,- \\
34.000,-\end{array}$ \\
\hline Penjaringan Sari IV & MBMB & $\begin{array}{l}\text { Seragam dalam } 1 \\
\text { Tower }\end{array}$ & $24 \mathrm{~m}^{2}$ & $\begin{array}{l}\text { Tertunggi } \\
\text { Terendah }\end{array}$ & $\begin{array}{l}96.000,- \\
62.000,-\end{array}$ \\
\hline Siwalankerto & Umum & $\begin{array}{l}\text { Bervariasi } \\
18 \mathrm{~m}^{2}, 24 \mathrm{~m}^{2}, 28 \mathrm{~m}^{2}, \\
30 \mathrm{~m}^{2}, 36 \mathrm{~m}^{2}, 48 \mathrm{~m}^{2}\end{array}$ & $24 \mathrm{~m}^{2}$ & $\begin{array}{l}\text { Tertunggi } \\
\text { Terendah }\end{array}$ & $\begin{array}{l}873.000,- \\
410.000,-\end{array}$ \\
\hline
\end{tabular}




\section{Analisis Perbandingan Fasilitas}

Penyelenggaran rumah susun wajib dilengkapi fasilitas lingkungan rumah susun berupa utilitas umum, prasarana dan sarana, dengan ketentuan luas lahan untuk fasilitas lingkungan rumah susun seluas-luasnya 30\% (tiga puluh persen) dari luas seluruhnya dan tidak ditempatkan lebih dari lantai 3 bangunan rumah susun hunian. Selain itu penyediaan lahan untuk fasilitas ruang terbuka, berupa taman sebagai penghijauan, tempat bermain anak-anak dan atau lapangan olah raga minimal 20\% dari seluruh luas lahan yang digunakan untuk fasilitas lingkungan rumah susun, sedangkan koefisien dasar bangunan (KDB) maksimum yang diizinkan 50\% dengan koefisien lantai bangunan (KLB) 1,25 (SNI 03-7013-2004).

Bentuk dan tipe unit sarusun pada Rusunawa Penjaringan Sari dan Rusunawa Warugunung dalam 1 blok memiliki ukuran yang seragam atau tidak memiliki variasi, dengan luas unit terkecil $18 \mathrm{~m}^{2}$ maksimal $24 \mathrm{~m}^{2}$ jika setiap hunian Rusunawa maksimal dihuni 4 orang maka kepadatan penduduk dalam satu bangunan cukup tinggi. Pada Rusunawa Penjaringan Sari dan Rusunawa Warugunung yang dibangun pada lahan seluas $\pm 30.000 \mathrm{~m}^{2}$ dengan jumlah tower masing-masing sebanyak 10 twin block, secara kasar luas lahan yang dimanfaatkan sebesar $\pm 3.000 \mathrm{~m}^{2}$ untuk setiap bangunan twin blok, sehingga jenis dan jumlah fasilitas lingkungan menjadi sangat terbatas dan sederhana menyesuaikan luas area yang dapat dimanfaatkan.

Fasilitas lingkungan yang ditempatkan di dalam lingkungan rumah susun sebagaimana yang tersedia pada Rusunawa Penjaringan Sari dan Warugunung adalah berupa fasilitas standar seperti fasilitas pelayanan umum pengelolaan rumah susun (berupa pos jaga, ruang serbaguna dan kantor pengelola), dan fasilitas yang merupakan penunjang pelaksanaan program Pemerintah Kota Surabaya berupa Posyandu, ruang belajar untuk Pendidikan Anak Usia Dini (PAUD) dan ruang board band learning center. Contoh fasilitas lingkungan di dalam lingkungan Rusunawa untuk kelompok MBR dan MBMB seperti pada Gambar 1 berikut.

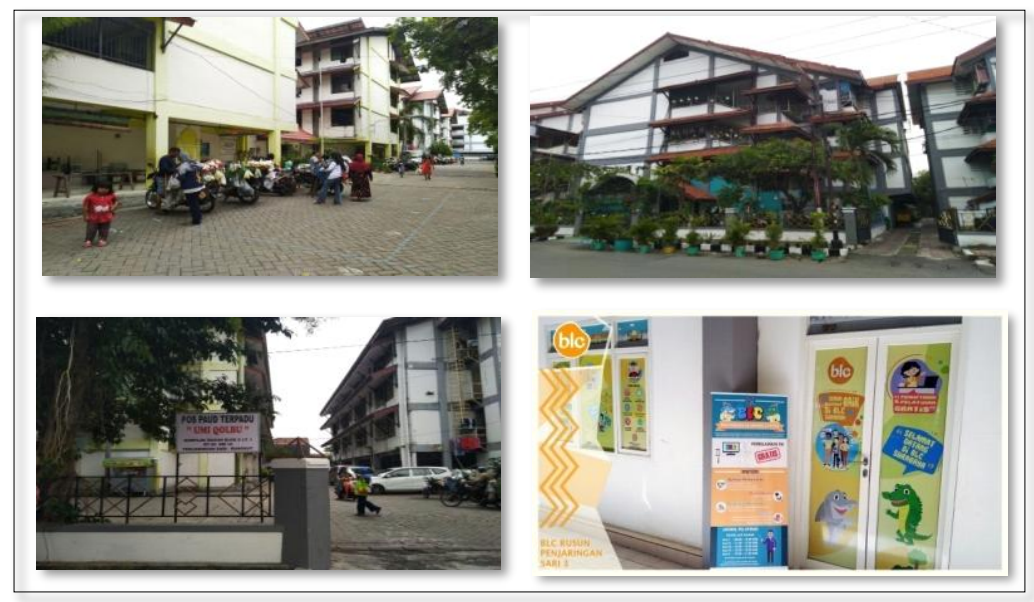

Gambar 1. Contoh Fasilitas di dalam Lingkungan Rumah Susun Penjaringan Sari

Keterbatasan area yang dapat dimanfaatkan untuk fasilitas lingkungan di dalam rumah susun diatasi dengan penyediaan fasilitas di luar lingkungan rumah halaman susun. Fasilitas lingkungan tersebut tidak hanya digunakan oleh warga penghuni rumah susun, namun juga dapat dimanfaatkan secara bersama-sama dengan warga umum non-penghuni rumah susun. Fasilitas lingkungan tersebut adalah fasilitas niaga berupa pasar kering dan sentra kuliner PKL maupun fasilitas pelayanan kota berupa taman kota dan lapangan olahraga. Contoh fasilitas yang ditempatkan di luar lingkungan Rusunawa disajikan dalam Gambar 2 berikut ini: 


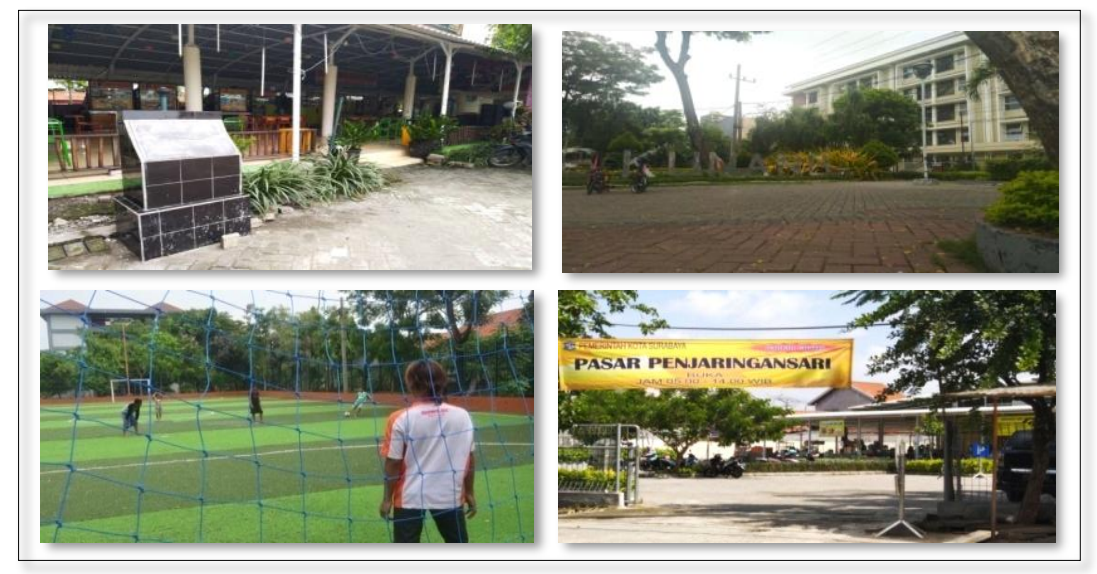

Gambar 2. Contoh Fasilitas di luar Lingkungan Rumah Susun Penjaringan Sari

Berbeda dengan Rusunawa Siwalankerto yang dalam setiap bloknya bervariasi dari yang kecil berkuran $18 \mathrm{~m}^{2}$ dan unit terluas berukuran $48 \mathrm{~m}^{2}$, maksimal jumlah penghuni pada Rusunawa Siwalankerto ditetapkan berdasarkan luasan per meter persegi unit sarusun. Rusunawa Siwalankerto memanfaatkan luas $\pm 22.000 \mathrm{~m}^{2}$ dengan 5 tower twin block, relatif memiliki luas lahan yang lebih lapang dibandingkan Rusunawa Penjaringan Sari dan Rusunawa Warugunung. Ketersediaan fasilitas yang ditempatkan di dalam lingkungan Rusunawa cukup beragam, baik berupa Fasilitas Niaga seperti kios komersial, pasar kering, food court, mini market, Fasilitas Kesehatan seperti klinik maupun Fasilitas Pendidikan PAUD. Berbagai fasilitas tersebut ditempatkan pada lantai dasar bangunan rumah susun dan ada yang berdiri pada bangunan terpisah. Contoh penyediaan fasilitas Rusunawa kelompok sasaran umum seperti pada Gambar 3 berikut:

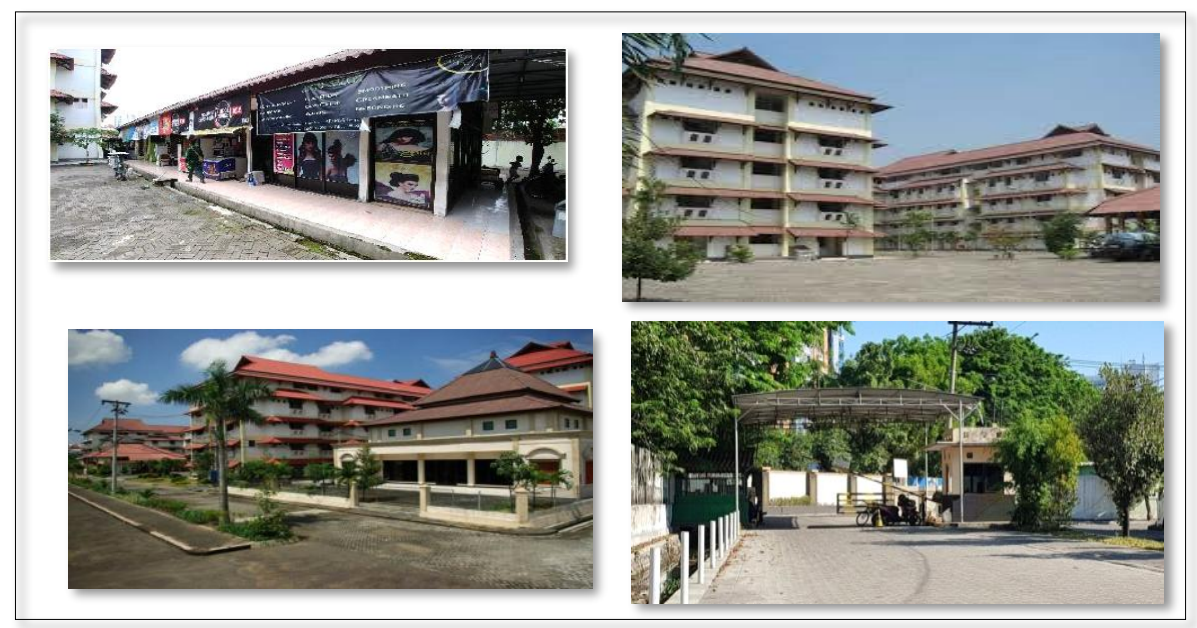

Gambar 3. Contoh Fasilitas di Dalam Lingkungan Rusunawa Siwalankerto

Dari hasil perbandingan penyediaan fasilitas, sangat bergantung pada luas lahan dan jumlah tower rumah susun yang dibangun. Rusunawa untuk kelompok penghuni MBR dan MBMB cenderung hanya tersedia fasilitas standar dan sederhana, untuk penempatan fasilitas dalam bentuk ruangan ditempatkan pada lantai dasar bangunan rumah susun, mengingat keterbatasan lahan yang tesedia kekurangan fasilitas disediakan di luar lingkungan Rusunawa. Berbeda dengan Rusunawa dengan kelompok penghuni umum, fasilitas yang tersedia lebih beragam dan bersifat komersil yang tidak hanya ditempatkan pada lantai dasar bangunan rumah susun tetapi juga ada berdiri pada bangunan. Perbandingan ketersediaan fasilitas lingkungan Rusunawa dalam penelitian ini dapat dilihat pada Tabel 10 berikut ini. 
Tabel 10. Rangkuman Perbandingan Fasilitas Rusunawa

\begin{tabular}{|c|c|c|c|}
\hline & \multicolumn{3}{|c|}{ Rusunawa } \\
\hline & Penjaringan Sari & Warugunung & Siwalankerto \\
\hline $\begin{array}{l}\text { Fasilitas di } \\
\text { dalam } \\
\text { lingkungan } \\
\text { rumah susun }\end{array}$ & $\begin{array}{l}\text { - Fasilitas Kesehatan } \\
\text { berupa Posyandu } \\
\text { - Fasilitas Pendidikan } \\
\text { berupa PAUD, dan } \\
\text { board band learning } \\
\text { center } \\
\text { - Fasilitas pelayanan } \\
\text { umum, seperti ruang } \\
\text { serbaguna } \\
\text { - Fasilitas ibadah berupa } \\
\text { mushola }\end{array}$ & $\begin{array}{l}\text { - Fasilitas Pendidikan } \\
\text { berupa PAUD, dan } \\
\text { board band learning } \\
\text { center } \\
\text { - Fasilitas pelayanan } \\
\text { umum, seperti ruang } \\
\text { serbaguna } \\
\text { - Fasilitas ibadah berupa } \\
\text { mushola }\end{array}$ & $\begin{array}{l}\text { - Fasilitas Niaga, berupa } \\
\text { kios komersial, pasar } \\
\text { kering, food court, } \\
\text { minimarket. } \\
\text { - Fasilitas Kesehatan } \\
\text { berupa klinik. } \\
\text { - Fasilitas Pendidikan } \\
\text { PAUD (TK dan } \\
\text { Kelompok Bermain) } \\
\text { - Fasilitas lapangan } \\
\text { olahraga } \\
\text { - Fasilitas pelayanan } \\
\text { umum, berupa ruang } \\
\text { serbaguna dan gedung } \\
\text { pendopo } \\
\text { - Fasilitas ibadah berupa } \\
\text { Mesjid }\end{array}$ \\
\hline $\begin{array}{l}\text { Fasilitas di luar } \\
\text { lingkungan } \\
\text { rumah susun }\end{array}$ & $\begin{array}{ll}\text { - } & \text { Pasar Kering } \\
\text { - } & \text { Taman Kota } \\
\text { - } & \text { Lapangan olahraga } \\
\text { - } & \text { Sentra kuliner PKL }\end{array}$ & $\begin{array}{l}\text { - Pasar Kering } \\
\text { - Taman Kota }\end{array}$ & $\begin{array}{l}\text { - Pasar Kering } \\
\text { - Taman Kota }\end{array}$ \\
\hline
\end{tabular}

\section{Rangkuman Analisis Perbandingan Penyelenggaraan Rusunawa}

Dari analisis yang telah dipaparkan sebelumnya mengenai penyelenggaran Rusunawa berkaitan kepemilikan, penghunian, lembaga pengelola, pembiayaan, luas unit, tarif dan penyediaan fasilitas terhadap 3 Rusunawa yang menjadi objek penelitian yaitu Rusunawa Penjaringan Sari, Rusunawa Warugunung dan Rusunawa Siwalankerto, diperoleh hasil bahwa rumah susun umum yang dibangun di atas tanah aset pemerintah dapat dimanfaatkan dengan cara sewa memiliki 3 kelompok sasaran penghuni yaitu, MBR, MBMB maupun masyarakat umum. Sumber pembiayaan pembangunan rumah susun dapat menggunakan APBN/APBD dan sumber pembiayaan lainnya, salah satunya adalah pola kerjasama antara pemerintah dengan sektor swasta. Dimana pengembalian investasi pembangunan infrastruktur yang dilaksanakan oleh sektor swasta dengan pengembalian investasi sepenuhnya menjadi tanggung jawab pemerintah dalam jangka waktu dan sistem kerjasama yang disepakati. Perbedaan penyelenggaraan Rusunawa yang didasarkan pada kelompok sasaran penghuni akan mempengaruhi penentuan lembaga pengelola, pembiayaan operasional, penetapatan tarif dan penyediaan fasilitas Rangkuman analisis perbandingan penyelenggaraan Rusunawa disajikan sebagaimana pada Tabel 11 berikut. 
Tabel 11. Hasil Perbandingan Penyelenggaraan Rusunawa Objek Penelitian

\begin{tabular}{|c|c|c|c|}
\hline & \multicolumn{3}{|c|}{ Rus unawa } \\
\hline & Penjaringan Sari & Warugunung & Siwalankerto \\
\hline $\begin{array}{l}\text { Fasilitas di } \\
\text { dalam } \\
\text { lingkungan } \\
\text { rumah susun }\end{array}$ & 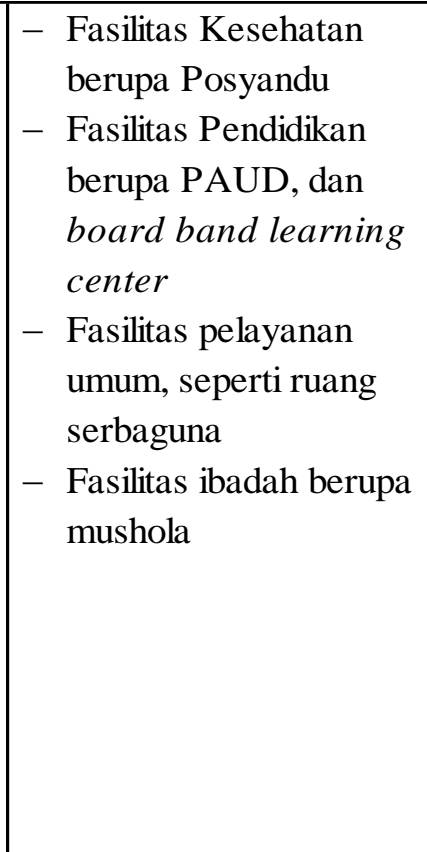 & $\begin{array}{l}\text { - Fasilitas Pendidikan } \\
\text { berupa PAUD, dan } \\
\text { board band learning } \\
\text { center } \\
\text { - Fasilitas pelayanan } \\
\text { umum, seperti ruang } \\
\text { serbaguna } \\
\text { - Fasilitas ibadah berupa } \\
\quad \text { mushola }\end{array}$ & $\begin{array}{l}\text { - Fasilitas Niaga, berupa } \\
\text { kios komersial, pasar } \\
\text { kering, food court, } \\
\text { minimarket. } \\
\text { - Fasilitas Kesehatan } \\
\text { berupa klinik. } \\
\text { - Fasilitas Pendidikan } \\
\text { PAUD (TK dan } \\
\text { Kelompok Bermain) } \\
\text { - Fasilitas lapangan } \\
\text { olahraga } \\
\text { - Fasilitas pelayanan } \\
\text { umum, berupa ruang } \\
\text { serbaguna dan gedung } \\
\text { pendopo } \\
\text { - Fasilitas ibadah berupa } \\
\text { Mesjid }\end{array}$ \\
\hline $\begin{array}{l}\text { Fasilitas di } \\
\text { luar } \\
\text { lingkungan } \\
\text { rumah susun }\end{array}$ & $\begin{array}{l}\text { - Pasar Kering } \\
\text { - Taman Kota } \\
\text { - Lapangan olahraga } \\
\text { - Sentra kuliner PKL }\end{array}$ & $\begin{array}{l}\text { - Pasar Kering } \\
\text { - Taman Kota }\end{array}$ & $\begin{array}{l}\text { - Pasar Kering } \\
\text { - Taman Kota }\end{array}$ \\
\hline
\end{tabular}

\section{KESIMPULAN}

Penelitian tentang identifikasi perbandingan penyelenggaraan Rusunawa memberikan kesimpulan sebagai berikut:

- Penyelenggaraan infrastruktur rumah susun yang dibangun di atas tanah aset pemerintah membutuhkan dukungan pembiayaan yang memadai sesuai dengan sasaran penghuni, luas unit, tarif, dan fasilitasnya. Infrastruktur rumah susun dapat dimanfaatkan dengan cara sewa, memiliki 3 kelompok sasaran penghuni yaitu, MBR, MBMB maupun masyarakat umum.

- Penyelenggaran rumah susun tidak hanya menjadi monopoli pemerintah, namun dapat pula melibatkan sektor swasta. Investasi pembangunan rumah susun sepenuhnya oleh pemerintah dan untuk pengembalian investasi sektor swasta pada tahap pembangunan menggunakan mekanisme angsuran sesuai Perjanjian Kerjasama yang disepakati.

- Penyelenggaraan Rusunawa dengan kelompok sasaran penghuni MBR dan MBMB dikelola sepenuhnya oleh Pemerintah melalui UPT Dinas terkait, tarif yang diberlakukan bersubsidi dan ditetapkan melalui Peraturan Kepala Daerah. Sedangkan, pada penghuni umum dapat dikelola dengan mekanisme kemitraan antara Pemerintah dan Swasta dengan pengenaan tarif komersial.

- Luas unit Rusunawa untuk MBR dan MBMB antara $18 m^{2}-24 m^{2}$ dengan tipe yang seragam setiap towernya. Sedangkan Rusunawa penghuni umum, memiliki tipe unit yang bervariasi pada setiap towernya dengan luasan unit antara $18 \mathrm{~m}^{2}-48 \mathrm{~m}^{2}$.

- Fasilitas yang disediakan sangat bergantung pada luas lahan dan jumlah tower hunian yang dibangun. Penyediaan fasilitas untuk penghuni MBR dan MBMB cenderung 
terbatas dan hanya berfungsi untuk memenuhi kebutuhan dasar penghuni. Sedangkan penghuni umum, fasilitas yang disediakan lebih beragam dan bersifat komersial.

\section{DAFTAR PUSTAKA}

AP Indonesia. (2008). "Rusunawa Siwalankerto Diresmikan". Berita Anggota Parlemen, 19 Agustus 2008. Diunduh pada tanggal Jumat, 13 Maret 2020 Jam 07.16 dari jariungu.com/berita_list.php?idBerita=67271

Kwik, Kian Gie. (2002). "Pembiayaan Pembangunan Infrastruktur dan Permukiman”. Materi Kuliah Disampaikan Pada Studium General Institut Teknologi Bandung

Mankew, N. G. (2004). Pengatar Ekonomi Mikro (3 ed.). (C. Sungkono, Penerj.) Salemba Empat. Jakarta.

Pergub Jawa Timur 39/09. Peraturan Gubernur Jawa Timur No. 39 Tahun 2009 tentang Penyerahan Aset Pemerintah Propinsi Jawa Timur.

Permen PPN/BAPPENAS 4/15. Peraturan Menteri Perencanaan Pembangunan Nasional/ Kepala Badan Perencanaan Pembangunan Nasional Republik Indonesia No. 04 Tahun 2015 tentang Tata Cara Pelaksanaan Kerjasama Pemerintah dengan Badan Usaha dalam Penyediaan Infrastruktur.

Permen PUPR 1/18. Peraturan Menteri Pekerjaan Umum dan Perumahan Rakyat Republik Indonesia No. 01 Tahun 2018 tentang Bantuan Pembangunan dan Pengelolaan Rumah Susun.

Perpres 38/15. Peraturan Presiden No. 38 Tahun 2015 tentang Kerjasama Pemerintah dengan Badan Usaha dalam Penyediaan Infrastruktur.

Perwali 5/20. Peraturan Walikota Surabaya No. 5 Tahun 2020 tentang Tarif Sewa Rumah Susun Sederhana Sewa dalam Pengelolaan Pemerintah Kota Surabaya.

PP 38/08. Peraturan Pemerintah Republik Indonesia No. 38 Tahun 2008 tentang Perubahan Atas Peraturan Pemerintah No. 6 Tahun 2006 tentang Pengelolaan Barang Milik Negara/Daerah.

Rachmawati, F., Soemitro, R.A.A., Adi, T.J.W. \& Susilawati, C. (2018). "Critical success factor for partnership in low-cost apartments project: Indonesia Perspective". Pacific Rim Property Research Journal, 24(2), pp. 149-160.

SNI 03-7013-2014. Standar Nasional Indonesia 03-7013-2014 tentang Tata Cara Perencanaan Fasilitas Lingkungan Rumah Susun Sederhana.

Soemitro, R.A.A. \& Suprayitno, H. (2018). "Pemikiran Awal tentang Konsep Dasar Manajemen Aset Fasilitas". Jurnal Manajemen Aset Infrastruktur \& Fasilitas, Vol. 2, Sup.1, Juni 2018, Hal. : 1-14.

Soemitro, R.A.A. \& Suprayitno, H. (2020). "Preliminary Reflection on Basic Problematics of National Public Infrastructure Financing in Indonesia". Journal of Infrastructure \& Facility Assets Management, Vol. 2, No.1, March 2020.

Subkhan, Mokh. (2008). Pengelolaan Rumah Susun Sederhana Sewa di Cengkareng Jakarta Barat. Tesis Pasca Sarjana. Universitas Diponegoro.

Suprayitno, H. \& Soemitro, R.A.A. (2018), "Preliminary Reflexion on Basic Principle of Infrastructure Asset Management". Jurnal Manajemen Aset Infrastruktur \& Fasilitas, Vol. 2, No.1, Maret 2018, Hal. : 1-10.

Suprayitno, H. \& Soemitro, R.A.A. (2019). "Reflection on Basic View of Public Infrastructure for Infrastructure Asset Management in Indonesia". Jurnal Manajemen Aset Infrastruktur \& Fasilitas, Vol. 3, Sup. 1, Juni 2019, Hal. : 15-24.

UU 20/11. Undang-Undang Republik Indonesia No. 20 Tahun 2011 tentang Rumah Susun.

Yudohusodo, Siswono. (1991). Rumah Untuk Seluruh Rakyat. Yayasan Padamu Negeri. Jakarta. 